\title{
Response surface methodology for the optimization of acid dye adsorption onto activated carbon prepared from wild date stones
}

\author{
Lamia Brahmi $^{1} \cdot$ Farida Kaouah $^{1} \cdot$ Salim Boumaza ${ }^{1} \cdot$ Mohamed Trari $^{2}$
}

Received: 19 April 2019 / Accepted: 1 October 2019 / Published online: 14 October 2019

(C) The Author(s) 2019

\begin{abstract}
In the present study, wild date stones (WDS) were used as a novel and sustainable precursor for high-quality activated carbon preparation to be applied for the removal of Acid Blue 25 dye (AB25) from synthetic water. The carbonization temperature of the raw material was selected at $850{ }^{\circ} \mathrm{C}$ on the basis of thermo-gravimetric analysis. The adsorbents were characterized by the BET method, Fourier transform infrared spectroscopy, and scanning electron microscopy. The results indicated that the activated carbon presents a high specific surface area $\left(610.84 \mathrm{~m}^{2} \mathrm{~g}^{-1}\right)$ and a pore volume $\left(0.224 \mathrm{~cm}^{3} \mathrm{~g}^{-1}\right)$ compared with the natural material. Based on the central composite design, the effect of different parameters such as the biomass dose, initial dye concentration, contact time and temperature was optimized and the optimal removal of AB25 (99.61\%) was achieved for $\mathrm{AB} 25$ concentration of $100 \mathrm{mg} \mathrm{L}^{-1}$ and an adsorbent dose of $0.8 \mathrm{~g} \mathrm{~L}^{-1}$, at $45^{\circ} \mathrm{C}$ after $120 \mathrm{~min}$. The kinetic studies indicated that the pseudo-second-order model was appropriately applied for the adsorption kinetic of AB25 onto wild date stones activated carbon. The intraparticle diffusion model is not the only controlling step, and other mechanisms may be involved in the adsorption process. The Langmuir isotherm provided the best fit with a high correlation coefficient $\left(R^{2}\right)$ of 0.993 and a maximum monolayer adsorption capacity of $181.59 \mathrm{mg} \mathrm{g}^{-1}$.
\end{abstract}

Keywords Activated carbon $\cdot$ Acid blue $25 \cdot$ Central composite design $\cdot$ Adsorption

\section{Introduction}

Dyes are used as coloring agents in various industries such as the textile, leather, paper, plastic, cosmetics, printing, pharmaceuticals, and food (Anithaa et al. 2016; Dashamiri et al. 2017; Jothirani et al. 2016). They generate colored wastewaters, depending on the fixation level of dye stuffs on the substrates, which change with the nature of the substance, the intensity of coloration, and the applied method (Amin 2009). Wastewaters coming from dyeing industries can be toxic to aquatic life by weakening the light flux which strongly inhibits the photosynthetic process (Kumar et al. 2018; Giannakoudakis et al. 2015) and can cause severe

Mohamed Trari

solarchemistry@gmail.com; mtrari@usthb.dz

1 Laboratory of Industrial Process Engineering Sciences, University of Sciences and Technology USTHB, 16111 Algiers, Algeria

2 Laboratory of Storage and Valorization of Renewable Energies, Faculty of Chemistry, University of Sciences and Technology USTHB, 16111 Algiers, Algeria effects to the human health (Suganya et al. 2017; Kumar et al. 2014a, b), due to their mutagenic and carcinogenic aspects (Jamshidi et al. 2016). Furthermore, some recalcitrant dyes are resistant to bio-degradation [Ghaedi et al. 2016; Bardajee et al. 2017; Khan et al. 2011). Hence, many treatments have been conducted for removing the dyes from the textile effluents (Kumar and Subramaniam 2013; Setiabudi et al. 2016). The adsorption is frequently used to diminish the color from effluents (Kumar et al. 2011) due to its simplicity of design and operation (Senthamarai et al. 2013; Kumar et al. 2015) and insensitivity to toxic substances (Kumar et al. 2014a, 2014b; Chatterjee et al. 2012; Kaçan and Kütahyah 2012). The commercial activated carbons with very large specific surface areas and pore structure possess high adsorption activities (Fernandez et al. 2014), but their applications remain limited because of their high cost. So, the use of inexpensive agriculture by-products to produce activated carbon provides an economical solution to these environmental problems (Deniz and Karaman 2011); one can cite activated carbon developed from the orange peels (Köseoğlu and Başar 2015), peanut shells (Georgin et al. 2016), and tomato (Lycopersicon esculentum 
Mill) (Say ğılı and Güzel 2016). The main objective of this research is devoted to the removal of the dye Acid Blue 25 (AB 25) from aqueous solution using activated carbon prepared from wild date stones (WDS).

Previous studies of dyes adsorption investigated the effect of individual parameters while maintaining the other constants at unspecified levels. However, this approach does not depict the combined effect of all parameters. This process is time-consuming and requires an increased number of experiments and more products to reach the optimum levels, which may be unreliable. These restrictions can be eliminated by optimizing the process parameters collectively by statistical experimental design such as the response surface methodology (RSM). In this respect, various parameters including the biomass dose, initial AB25 concentration $\left(C_{0}\right)$, contact time, and temperature were optimized by central composite design (CCD) combined with (RSM).

\section{Materials and methods}

\section{Materials}

Wild date stones (WDS) were used as precursor material for the preparation of activated carbon. They were collected from the University campus (Algiers), thoroughly washed with distilled water to remove dust, and dried at $105^{\circ} \mathrm{C}$ for $24 \mathrm{~h}$.

The carbonization temperature of the natural material was investigated by Thermogravimetric Analyzer model (SDT Q600, TA instruments); the biomass was heated up to $1000{ }^{\circ} \mathrm{C}$ at a heating rate of $10{ }^{\circ} \mathrm{C} \mathrm{min}^{-1}$ under $\mathrm{N}_{2}$ atmosphere $\left(100 \mathrm{~mL} \mathrm{~min}^{-1}\right)$. The carbonization temperature can be selected by plotting the weight loss percentage versus temperature. It is observed from Fig. 1 that the weight loss percentage was negligible up to $850{ }^{\circ} \mathrm{C}$, indicating that the main structure of char was formed. So, this temperature was selected for the carbonization of WDS biomass.

The pyrolysis of the raw material was performed in a carbonization device under $\mathrm{N}_{2}$ atmosphere. The sample was heated at $900{ }^{\circ} \mathrm{C}\left(10{ }^{\circ} \mathrm{C} \mathrm{min}{ }^{-1}\right)$ under $\mathrm{N}_{2}$ flow $\left(150 \mathrm{~mL} \mathrm{~min}{ }^{-1}, 2 \mathrm{~h}\right)$ in a tubular furnace. Following the carbonization, the chars were heated under $\mathrm{N}_{2}$ flow up to $850{ }^{\circ} \mathrm{C}$. Once the final temperature was reached, $\mathrm{N}_{2}$ flow was switched to $\mathrm{CO}_{2}$ and activated for $2 \mathrm{~h}$. Finally, the $\mathrm{CO}_{2}$ flow was replaced with $\mathrm{N}_{2}$ during cooling to room temperature. The samples were kept in desiccators for further use.

The Acid Blue 25 dye (AB25: $\mathrm{C}_{20} \mathrm{H}_{13} \mathrm{~N}_{2} \mathrm{NaO}_{5} \mathrm{~S}$; $\mathrm{MW}=416.38 \mathrm{~g} \mathrm{~mol}^{-1}$; chemical index (CI) of 62055) was purchased from the textile Algerian Company and is characterized by a weak biodegradability and high toxicity. The adsorption tests were performed on synthetic solutions prepared with non-purified commercial product.

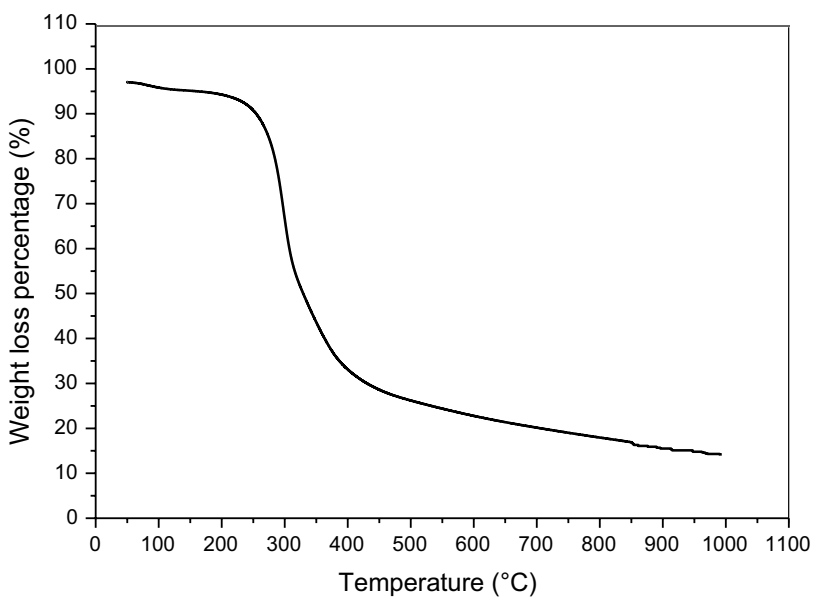

Fig. 1 TGA curve of natural material

To visualize the surface morphology of WDS and WDSAC, scanning electron microscopy (SEM, JEOL JSM-6360) was used. The specific surface areas of adsorbents were measured from the $\mathrm{N}_{2}$ adsorption-desorption isotherm using a Micrometrics ASAP 2010 V5.00 H Surface Analyzer in the relative pressure $\left(P / P_{0}=0.308\right)$. The micropore volumes were evaluated with the accumulative pore volume using the t-plot method. The total pore volume was calculated from the volumes of $\mathrm{N}_{2}$ absorbed at relative pressure $\left(P / P_{0}=0.349\right)$. In order to identify the functional groups of WDS and WDSAC, the Fourier transform infrared spectroscopy (FTIR, PerkinElmer spectrometer) was carried out in the range (400-4000 $\mathrm{cm}^{-1}$ ) by mixing $1 \mathrm{mg}$ of adsorbents with $200 \mathrm{mg}$ of $\mathrm{KBr}$ (spectroscopic quality) to get translucent disk.

\section{Procedure and analysis}

All adsorption tests were done in batch mode according to the same experimental protocol. A stock solution of $1000 \mathrm{mg} \mathrm{L}^{-1}$ was prepared by dissolving AB25 in distilled water and stored in glass bottles. The solutions of various AB25 concentrations were made up by dilution; the $\mathrm{pH}$ was natural without any adjustment. In the batch method, fixed quantities of adsorbent were added in the specific volume of AB25 solutions and agitated at $400 \mathrm{rpm}$ at controlled temperature until equilibrium. The aqueous samples were immediately centrifuged for $5 \mathrm{~min}$ at $4000 \mathrm{rpm}$ for $15 \mathrm{~min}$. The final AB25 concentrations were analyzed with a double-beam UV-visible spectrophotometer (Specord 210 Plus Analytik Jena) at the maximum wavelength $(602 \mathrm{~nm})$. The percentage of AB25 removed by the adsorbent $(Y)$ was calculated from the following equation (Boumaza et al. 2012; Prola et al. 2013):

$Y(\%)=\frac{C_{0}-C_{e}}{C_{0}} * 100$ 
where $C_{0}$ and $C_{e}\left(\mathrm{mg} \mathrm{L}^{-1}\right)$ are the liquid-phase concentrations of $\mathrm{AB} 25$ at $t=0$ and equilibrium, respectively. The amounts $q_{e}\left(\mathrm{mg} \mathrm{g}^{-1}\right)$ adsorbed per unit mass of adsorbent are evaluated from the following formula (Kaouah et al. 2013):

$q_{e}=\frac{\left(C_{0}-C_{e}\right) * V}{m}$

where $V$ is the volume of the dye solution $(\mathrm{mL})$ and $m$ the adsorbent dose $(g)$.

RSM is a group of statistical and mathematical techniques for analyzing and evaluating the interactive effect of several variables taken from the fit of empirical models to the experimental data [Arulkumar et al. 2011; Vecino et al. 2012; Fakhri 2015). In this work, four independent parameters were investigated by using RSM under CCD method, including the AB25 concentration $\left(X_{1}\right)$, adsorbent dose $\left(X_{2}\right)$ temperature $\left(X_{3}\right)$, and time $\left(X_{4}\right)$. These variables were set in five levels to evaluate the influence of the quantities of removal yield for the optimization process. The independent variables are coded in the range $(-1,+1)$ with a low $(-1)$ and high levels $(+1)$. The axial points are located at a distance $\alpha$ from the center, making the design rotatable (Roosta et al. 2014) and $\alpha$ fixed at 2 (rotatable). Replicates of the test at the center are very important since they provide an independent estimation of the experimental errors and a reproducibility of the data runs (Cronje et al. 2011). For four variables, the recommended number of tests at the center is 6 . Therefore, the number of experimental runs is calculated as follows (Chatterjee et al. 2012; Azargohar and Dalai 2005):

$N=2^{n}+2 n+n_{c}=30(n=4)$

The range and levels of the independent numerical parameters in terms of actual and coded values are given in Table 1.

The mathematical relationship between the four independent factors can be approximated by the second-order polynomial model (Eq. 4) (Cronje et al. 2011):

$Y=\beta_{0}+\sum_{i=1}^{n} \beta_{i} X_{i}+\sum_{i=1}^{n} \beta_{i i} X_{i}^{2}+\sum_{i=1}^{n-1} \sum_{j=1}^{n} \beta_{i j} X_{i} X_{j}$

where $Y$ is the predicted response (removal percentage) and $X_{i}$ 's the independent variables (AB25 concentration, adsorbent dose, temperature, and time) known for each experimental run. The parameter $\beta_{0}$ is the model constant, $\beta_{i}$ the linear coefficient, $\beta_{i i}$ the quadratic coefficients, and $\beta_{i j}$ the cross-product coefficients. The analysis of variance (ANOVA) method is applied to estimate the significance level of factors (Cheng et al. 2015; Hou et al. 2012).

\section{Results and discussion}

\section{Surface characteristics}

The SEM micrographs of WDS and WDS-AC are shown in Fig. 2. A significant difference between the morphology of both adsorbents is observed. Unlike smooth surface of WDS (Fig. 2a, b), the surface of WDS-AC (Fig. 2c, d) is coarse with lots of micropores and holes, where there is a good possibility for the dye to be adsorbed inside these pores. The improvement of the surface relief of the adsorbent after activation and carbonization is confirmed by the augmentation of the BET surface area and total pore volume of adsorbents. The surface area and pore volume of WDS were $0.134 \mathrm{~m}^{2} \mathrm{~g}^{-1}$ and $0.00048 \mathrm{~cm}^{3} \mathrm{~g}^{-1}$, respectively, and increase up to $610.843 \mathrm{~m}^{2} \mathrm{~g}^{-1}$ and $0.224 \mathrm{~cm}^{3} \mathrm{~g}^{-1}$ for WDS-AC.

The FTIR spectra of the precursor and WDS-AC are illustrated in Fig. 3. It can be seen that the structure of WDS is rich in functional groups than WDS-AC, thus revealing the complex nature of the precursor. The bands $(\mathrm{O}-\mathrm{H})$ at $3435 \mathrm{~cm}^{-1}$ and $(\mathrm{C}-\mathrm{H})$ at 2921 and $2856 \mathrm{~cm}^{-1}$ observed for both samples are attributed to hydroxyl, methyl and methylene groups, respectively. Additionally, the intensity of the bands between 1750 and $1450 \mathrm{~cm}^{-1}$ diminishes for the activated carbon compared with the natural precursor, due to the activating action of $\mathrm{CO}_{2}$ at high temperature. The absorption band at $1746 \mathrm{~cm}^{-1}$ indicates the existence of carboxyl or aldehydes functional group $(\mathrm{C}=\mathrm{O})$, while the peak $1641 \mathrm{~cm}^{-1}$ is assigned to alkenes bands $(\mathrm{C}=\mathrm{C})$. From the FTIR spectrum of activated carbon, many bands disappeared in the range $\left(1400-500 \mathrm{~cm}^{-1}\right)$ while others emerged. The vanished peaks related to the aromaticity of the material increased during activation. The peak at $1385 \mathrm{~cm}^{-1}$ is attributed to the presence of $\left(\mathrm{CH}_{3}\right.$ and- $\left.\mathrm{CH}_{2}\right)$, whereas the broadband of $\mathrm{C}-\mathrm{O}-\mathrm{C}$ stretching vibration is observed at
Table 1 Experimental range and levels of the independent variables for $\mathrm{AB} 25$ adsorption

\begin{tabular}{lllllrl}
\hline Variables & Symbol & $-\alpha$ & -1 & 0 & +1 & $+\alpha$ \\
\hline Initial concentration $\left(\mathrm{mg} \mathrm{L}^{-1}\right)$ & $X_{1}$ & 50 & 100 & 150 & 200 & 250 \\
Adsorbent dose $\left(\mathrm{g} \mathrm{L}^{-1}\right)$ & $X_{2}$ & 0.1 & 0.4 & 0.7 & 1 & 1.3 \\
Temperature $\left({ }^{\circ} \mathrm{C}\right)$ & $X_{3}$ & 15 & 25 & 35 & 45 & 55 \\
Time $(\min )$ & $X_{4}$ & 30 & 60 & 90 & 120 & 150 \\
\hline
\end{tabular}


Fig. 2 SEM micrographs of WDS: $(\mathbf{a}, \mathbf{b})$ and WDS-AC: $(\mathbf{c}, \mathbf{d})$
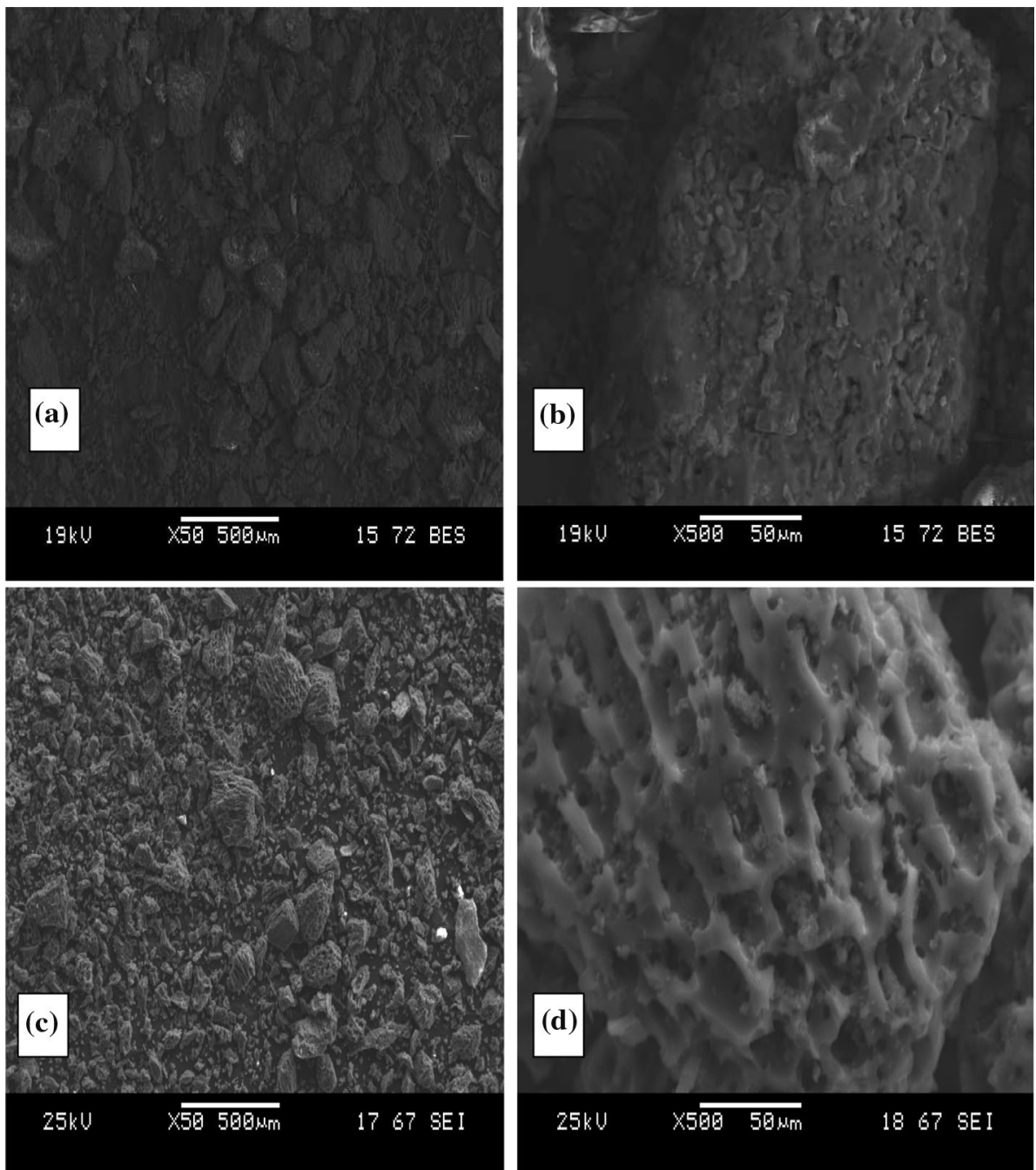

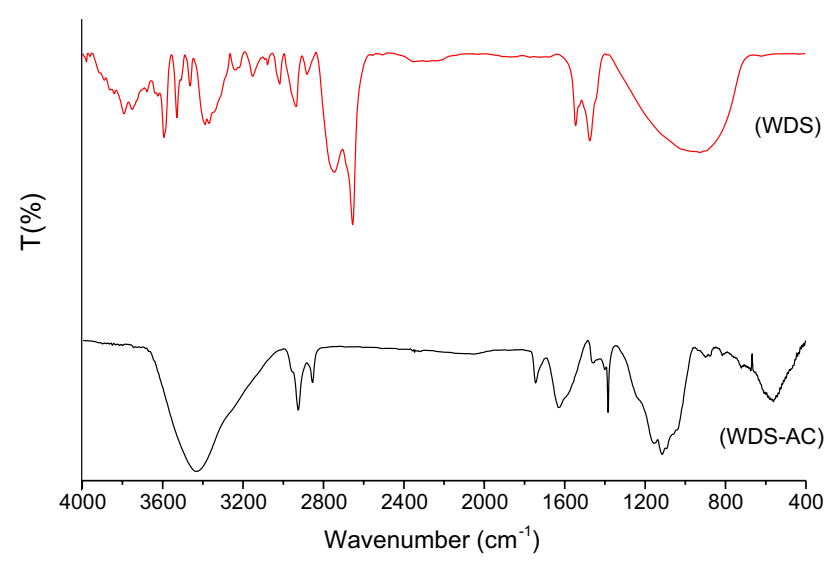

Fig. 3 FTIR spectra of precursor and WDS-AC

$1120 \mathrm{~cm}^{-1}$. Finely, the new peak at $1540 \mathrm{~cm}^{-1}$ corresponds to the $\mathrm{C}-\mathrm{C}$ stretching vibration.

\section{Experimental design results}

The CCD matrix coupled with the predicted and actual results is given in Table 2; the GMP 8.0.2 software is used for the regression and graphical analysis of the obtained data. The sum of squares, mean squares, estimated coefficient, $F$ values, and $p$ values are also tested using ANOVA, and the results are regrouped in Table 3 . In statistic, a model with large $F$ value and small $p$ value $(<0.05)$ is considered to be significant (Hou et al. 2012). So, it can be concluded that the coefficients for the linear effect of all factors: initial AB25 concentration $C_{0}\left(\mathrm{X}_{1}\right)$, adsorbent dose $\left(X_{2}\right)$, temperature $\left(X_{3}\right)$, and time $\left(X_{4}\right)(P<0.05$ for all $)$, are highly significant (Table 3). Moreover, the coefficients of the quadratic effect of $\mathrm{AB} 25$ concentration $\left(X_{1} * X_{1}\right)$, adsorbent dose $\left(X_{2} * X_{2}\right)$, and time $\left(X_{4} * X_{4}\right)(P<0.05$ for all $)$ are considered as significant, while the quadratic effect of temperature $\left(X_{3} * X_{3}\right)$ does not seem significant with high $P$ value $(P=0.2976)$. In the interaction effect, none of the variables was found to be significant except between the AB25 concentration $\left(X_{1}\right)$ and 
Table 2 Data statistics of model variables

\begin{tabular}{|c|c|c|c|c|c|c|}
\hline \multirow[t]{2}{*}{ Run } & \multicolumn{4}{|c|}{ Coded values } & \multicolumn{2}{|l|}{ Removal \% } \\
\hline & $X_{1}$ & $X_{2}$ & $X_{3}$ & $X_{4}$ & Experimental & Predicted \\
\hline 1 & $200(+1)$ & $0.8(+1)$ & $25(-1)$ & $120(+1)$ & 64.6659 & 65.7999 \\
\hline 2 & $200(+1)$ & $0.8(+1)$ & $45(+1)$ & $60(-1)$ & 70.6445 & 67.4265 \\
\hline 3 & $200(+1)$ & $0.4(-1)$ & $45(+1)$ & $120(+1)$ & 61.0675 & 61.9851 \\
\hline 4 & $200(+1)$ & $0.4(-1)$ & $25(-1)$ & $60(-1)$ & 59.7382 & 54.3552 \\
\hline 5 & $100(-1)$ & $0.8(+1)$ & $45(+1)$ & $120(+1)$ & 99.6374 & 104.500 \\
\hline 6 & $100(-1)$ & $0.4(-1)$ & $45(+1)$ & $60(-1)$ & 61.5498 & 59.8951 \\
\hline 7 & $100(-1)$ & $0.4(-1)$ & $25(-1)$ & $120(+1)$ & 50.8957 & 53.5931 \\
\hline 8 & $100(-1)$ & $0.8(+1)$ & $25(-1)$ & $60(-1)$ & 77.4976 & 76.0594 \\
\hline 9 & $150(0)$ & $0.6(0)$ & $35(0)$ & $90(0)$ & 56.1548 & 56.3485 \\
\hline 10 & $150(0)$ & $0.6(0)$ & $35(0)$ & $90(0)$ & 54.4598 & 56.3485 \\
\hline 11 & $150(0)$ & $0.6(0)$ & $35(0)$ & $90(0)$ & 60.1284 & 58.0107 \\
\hline 12 & $100(-1)$ & $0.4(-1)$ & $45(+1)$ & $120(+1)$ & 67.0735 & 68.6968 \\
\hline 13 & $150(0)$ & $0.6(0)$ & $35(0)$ & $90(0)$ & 58.9872 & 58.0107 \\
\hline 14 & $100(-1)$ & $0.8(+1)$ & $25(-1)$ & $120(+1)$ & 88.5592 & 88.6495 \\
\hline 15 & $100(-1)$ & $0.4(-1)$ & $25(-1)$ & $60(-1)$ & 43.3412 & 46.3879 \\
\hline 16 & $200(+1)$ & $0.8(+1)$ & $45(+1)$ & $120(+1)$ & 76.5654 & 74.2922 \\
\hline 17 & $200(+1)$ & $0.8(+1)$ & $25(-1)$ & $60(-1)$ & 61.3803 & 60.5306 \\
\hline 18 & $100(-1)$ & $0.8(+1)$ & $45(+1)$ & $60(-1)$ & 96.7393 & 96.9622 \\
\hline 19 & $200(+1)$ & $0.4(-1)$ & $45(+1)$ & $60(-1)$ & 59.8211 & 60.5043 \\
\hline 20 & $200(+1)$ & $0.4(-1)$ & $25(-1)$ & $120(+1)$ & 60.3377 & 60.8884 \\
\hline 21 & $150(0)$ & $0.6(0)$ & $35(0)$ & $90(0)$ & 57.9463 & 57.2779 \\
\hline 22 & $50(-2)$ & $0.6(0)$ & $35(0)$ & $90(0)$ & 99.1137 & 94.5150 \\
\hline 23 & $150(0)$ & $0.6(0)$ & $55(+2)$ & $90(0)$ & 71.9163 & 71.4610 \\
\hline 24 & $150(0)$ & $0.2(-2)$ & $35(0)$ & $90(0)$ & 47.4866 & 46.3724 \\
\hline 25 & $150(0)$ & $0.6(0)$ & $15(-2)$ & $90(0)$ & 49.2591 & 49.4615 \\
\hline 26 & $150(0)$ & $0.6(0)$ & $35(0)$ & $30(-2)$ & 52.8499 & 57.2717 \\
\hline 27 & $150(0)$ & $1(+2)$ & $35(0)$ & $90(0)$ & 87.4897 & 88.3509 \\
\hline 28 & $250(+2)$ & $0.6(0)$ & $35(0)$ & $90(0)$ & 67.9289 & 72.2746 \\
\hline 29 & $150(0)$ & $0.6(0)$ & $35(0)$ & $150(+2)$ & 76.0174 & 71.3426 \\
\hline 30 & $150(0)$ & $0.6(0)$ & $35(0)$ & $90(0)$ & 55.5976 & 57.2779 \\
\hline
\end{tabular}

Table 3 Analysis of variance (ANOVA) of the factors on the responses

\begin{tabular}{lllccrr}
\hline Term & Estimated coefficient & $D F$ & Sum of squares & Mean squares & $F$ value & $p$ values \\
\hline Constant & 57.2123 & 1 & 133,140 & 133,140 & - & $<0.0001$ \\
$X_{1}$ & -5.5901 & 1 & 741.9564 & 741.9564 & 50.2877 & $<0.0001$ \\
$X_{2}$ & 10.4947 & 1 & 2643.2938 & 2643.2938 & 179.1551 & $<0.0001$ \\
$X_{3}$ & 5.4999 & 1 & 725.9681 & 725.9681 & 49.2041 & $<0.0001$ \\
$X_{4}$ & 3.5178 & 1 & 296.9846 & 296.9846 & 20.1288 & 0.0006 \\
$X_{1} * X 2$ & 6.5292 & 1 & 719.3352 & 719.3352 & 48.7545 & $<0.0001$ \\
$X_{1} * X_{3}$ & 2.5210 & 1 & 114.1153 & 114.1153 & 7.73344 & 0.0156 \\
$X_{2} * X_{3}$ & 0.7958 & 1 & 16.5741 & 16.5741 & 1.1233 & 0.3085 \\
$X_{1} * X_{4}$ & 1.7573 & 1 & 15.971 & 15.971 & 1.08225 & 0.3171 \\
$X_{2} * X_{4}$ & -6.7051 & 1 & 4.2458 & 4.2458 & 0.2878 & 0.6007 \\
$X_{3} * X_{4}$ & -2.6706 & 1 & 2.9861 & 2.9861 & 0.2024 & 0.6602 \\
$X_{1} * X_{1}$ & -0.999 & 1 & 1169.3025 & 1169.3025 & 79.2521 & $<0.0001$ \\
$X_{2} * X_{2}$ & 1.0178 & 1 & 175.3125 & 175.3125 & 11.8144 & 0.0044 \\
$X_{3} * X_{3}$ & 0.5152 & 1 & 17.3717 & 17.3717 & 1.1774 & 0.2976 \\
$X_{4} * X_{4}$ & -0.4319 & 1 & 84.7038 & 84.7038 & 5.7410 & 0.0323 \\
\hline
\end{tabular}


Table 4 The ANOVA for the full quadratic model for $R \%$ of $\mathrm{AB} 25$

\begin{tabular}{lrlllllll}
\hline & $D F$ & Sum of squares & Mean squares & $F$ value & $p$ values & $R^{2}$ & $R_{\text {adj }}^{2}$ & $Q^{2}$ \\
\hline Model & 11 & 6493.9617 & 590.360 & 42.6846 & $<0.0001$ & 0.9631 & 0.941 & 0.878 \\
Residual & 18 & 248.9535 & 13.831 & - & - & & & \\
Lack of fit & 15 & 244.1076 & 16.2738 & 3.3958 & 0.091 & & & \\
Pure error & 3 & 4.8459 & 1.6153 & - & 0.0408 & & & \\
Total corrected & 29 & 6742.9152 & 232.515 & - & - & & & \\
Total & 30 & 139,391 & 4646.35 & - & - & & &
\end{tabular}

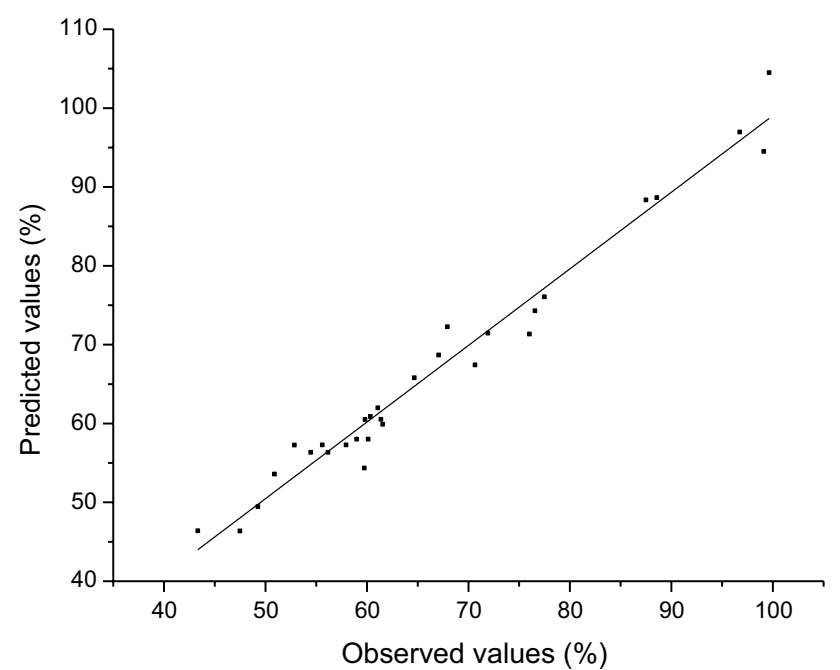

Fig. 4 The predicted data versus the experimental data of normalized removal of $\mathrm{AB} 25$ dye

adsorbent dose $\left(X_{2}\right)(P<0.0001)$ and concentration $C_{0}\left(X_{1}\right)$ and temperature $\left(X_{3}\right)(P<0.05)$.

According to the experimental data, the quadratic regression model where the insignificant terms are not included is described by the relation:

$$
\begin{aligned}
Y & =57.2123-5.5601 x_{1}+10.4947 x_{2}+5.4999 x_{3} \\
& +3.5178 x_{4}+6.5292 x_{1}^{2}+2.521 x_{2}^{2} \\
& +1.7573 x_{4}^{2}-6.7051 x_{1} x_{2}-2.6706 x_{1} x_{3}
\end{aligned}
$$

Fig. 5 Normal probability plots of residuals for \% removal of $\mathrm{AB} 25$ dye
A positive sign in the equation represents a synergistic effect of the variables, while a negative sign indicates an antagonistic effect (Garba et al. 2016). The fit of models is evaluated by the correlation coefficient $R^{2}$ and adjusted coefficient $R^{2}\left(R_{\text {adj }}^{2}\right)$ (Chatterjee et al. 2012). The high values of $R^{2}(=0.963)$ and $R_{\text {adj }}^{2}(=0.941)$ indicate that the response surface quadratic model is appropriate for predicting the performance of AB25 removal (Table 4). The predicted correlation coefficient $\left(Q^{2}=0.878\right)$ agrees with the coefficient $R_{\text {adj }}^{2}$. Moreover, both $F(=42.6846)$ and $p(<0.0001)$ proof statistically significance of the model.

The fitted quality of Eq. 5 is also expressed through the AB25 adsorption between experimental and predicted models (Fig. 4) with a good agreement between the actual and predicted values of AB25 removal, indicating the goodness of fit and reliability of the model $\left(R^{2}=0.969\right)$.

\section{Residuals normal probability plot for the reduced model}

One of the essential hypotheses for the statistical analysis of the experimental data is their normal distribution (Asfaram et al. 2016). The normal possibility for studentized residuals is illustrated in Fig. 5. The distribution of residuals is normal, if the experimental data follow a straight line (Dastkhoon et al. 2015). It is clear that the experimental points are normally distributed with no outliers and located on the normal line spread out between -4 and +4 studentized residuals (Fig. 5).

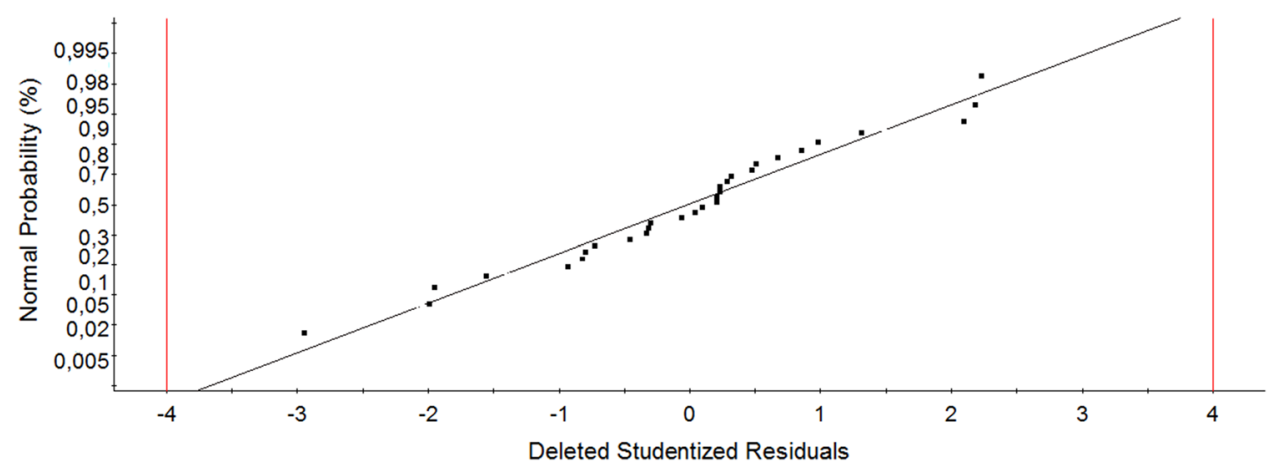




\section{Interactive effects of different parameters on adsorption of AB25 dye}

The relation between different factors and responses is elucidated by the exploration of contour plots as a function of two factors by maintaining the other factors at central level. In the present work, the effect of the AB25 concentration on its removal percentage and its interaction with the adsorbent dose and temperature are illustrated in Fig. 6a, b, respectively. The curvature natures of these plots prove the interaction of variables.

Figure 6a represents the interaction between the AB25 concentration and adsorbent dose and their influence for the removal percentage. The augmentation of the initial AB25 concentration $C_{0}$ from 100 to $200 \mathrm{mg} \mathrm{L}^{-1}$ is associated with the diminution of the removal percentage. This may be due to the fact that the ratio of adsorption sites in comparison to adsorbate AB25 dye becomes smaller and not sufficient to interact with adsorbate species, leading to decreased removal efficiency (Mazaheri et al. 2016). In contrast, the adsorbent dose has a positive effect on the percentage removal which improves from low $\left(0.4 \mathrm{~g} \mathrm{~L}^{-1}\right)$ to high value $\left(0.8 \mathrm{~g} \mathrm{~L}^{-1}\right)$. This behavior evidently indicates that the augmentation of adsorbent dose increases the number of active sites and improves the interaction adsorbate/adsorbent.

In adsorption, the temperature plays an important role; Fig. $6 \mathrm{~b}$ shows the contour plot representing the composed influence of AB25 concentration $C_{0}$ and temperature. With augmenting the temperature from 25 to $45^{\circ} \mathrm{C}$, the percentage of $\mathrm{AB} 25$ removal increases because of the higher active surface area and kinetic energy of AB25 molecules. In other view, the increase in the diffusion rate of $\mathrm{AB} 25$ molecules at higher temperature across the boundary layer and inside the pores results from the decrease in the solution viscosity (Sivarajasekar and Baskar 2014).

\section{Process optimization}

The best local maximum was determined by the reduced model: $\mathrm{AB} 25$ concentration $C_{0}$ of $100 \mathrm{mg} \mathrm{L}^{-1}$, adsorbent dose $\left(0.8 \mathrm{~g} \mathrm{~L}^{-1}\right)$, temperature $\left(45^{\circ} \mathrm{C}\right)$, and adsorption time (120 min). Under these optimal conditions, the maximum AB25 elimination from aqueous solution by adsorption approaches $100 \%$. These optimum parameters were experimentally checked to verify the adequacy of the model with a removal of $99.61 \%$. The percentage error between the actual and predicted values is very small; this corroborates the result of the response surface optimization and indicates that the suggested model is adequate for getting the optimum values for the studied factors.

\section{Kinetic study}

The kinetics is fundamental for the adsorption of AB25 (Aljeboree et al. 2017), and it characterizes the rate-limiting step and elucidates the adsorption process (Sivarajasekar and Baskar 2014; Bouhamidi et al. 2018). In this respect, three models, namely the pseudo-first order, pseudo-second order, and intraparticle diffusion, were tested to evaluate the experimental data.

The pseudo-first-order model proposed by Lagergren and Ho and pseudo-first-order model developed by McKay are defined by Eqs. 6 and 7 (Deze et al. 2012; Puchana-Rosero et al. 2016), and the model parameters and regression coefficient $\left(R^{2}\right)$ are evaluated by the nonlinear regression using the ORIGIN 8.6 software.
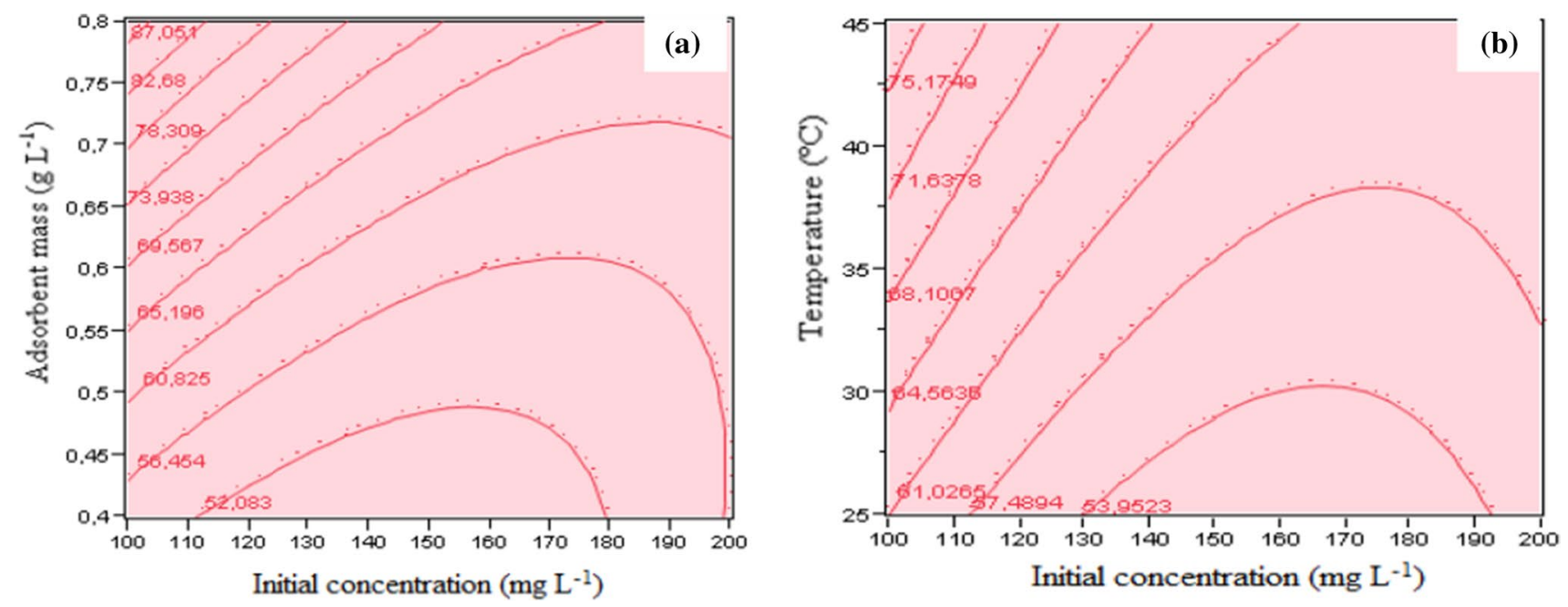

Fig. 6 Contour plots indicating interaction effects of independent variables on variation of removal percentage: a initial concentration-adsorbent mass; b initial concentration-temperature 
$q_{t}=q_{e} \times\left[1-\exp \left(-k_{1} \times t\right)\right]$

$q_{t}=\frac{k_{2} q_{e}^{2} t}{1+k_{2} q_{e} t}$

where $q_{e}\left(\mathrm{mg} \mathrm{g}^{-1}\right)$ is the amount of AB25 adsorbed at equilibrium, $q_{t}\left(\mathrm{mg} \mathrm{g}^{-1}\right)$ the amount of AB25 adsorbed at time $t$ (min), $k_{1}\left(\mathrm{~min}^{-1}\right)$ the pseudo-first-order rate constant, and $k_{2}\left(\mathrm{~g} \mathrm{mg}^{-1} \mathrm{~min}^{-1}\right)$ the rate constant of pseudo-second order.

In addition to the coefficient $\left(R^{2}\right)$, the Chi-square statistical test $\left(\chi^{2}\right)$ is also calculated to select the best model to the experimental data (Unuabonah et al. 2009)

$\chi^{2}=\sum_{i=1}^{n} \frac{\left(q_{e, \mathrm{exp}}-q_{e, \mathrm{cal}}\right)^{2}}{q_{e, \mathrm{cal}}}$

where $n$ is the number of data points, $q_{e, \text { exp }}$ the observation from the experiments, and $q_{e, \text { cal }}$ the calculation from the models.

(a)

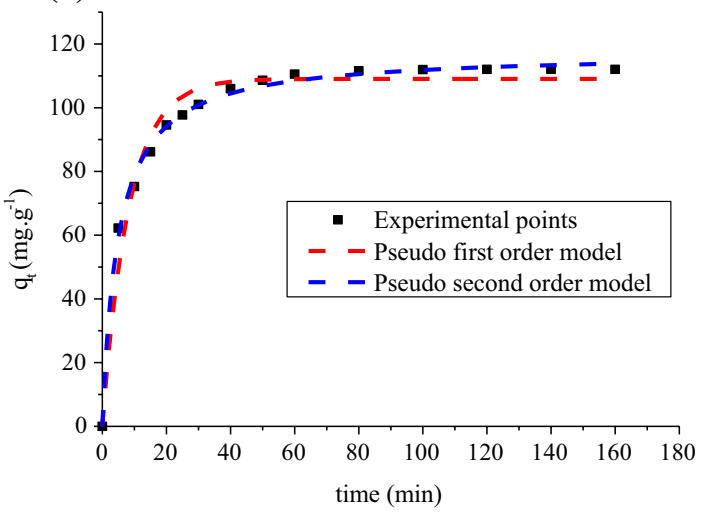

The data are fitted for both models in the concentrations range $(90-150 \mathrm{mg} / \mathrm{L})$, maintaining the other parameters at their optimum values (adsorbent dose $0.8 \mathrm{~g} \mathrm{~L}^{-1}$, temperature $45^{\circ} \mathrm{C}$, and adsorption time $120 \mathrm{~min}$ ) which are illustrated in Fig. 7 , and the corresponding kinetic parameters $\left(R^{2}\right.$ and $\left.\chi^{2}\right)$ are gathered in Table 5.

On the basis of $R^{2}$ and $\chi^{2}$ for both models (Table 5), the experimental data are well fitted by the pseudo-second-order model with the initial concentrations. Additionally, the $k_{2}$ values for the AB25 system diminishes with augmenting the $\mathrm{AB} 25$ concentration $C_{0}$; the reason for this phenomenon can be attributed to the small competition for the surface active sites at lower dye concentration. On the contrary, at higher concentrations, the competition for the adsorption sites increases leading to lower $k_{2}$ values (Sayğılı and Güzel 2016).

The intraparticle diffusion model proposed by Weber and Morris (Weber and Morris 1963; Kumar et al. 2010a, b) is represented mathematically by the following relation:

$q_{t}=k_{\mathrm{dif}} t^{0.5}+C$
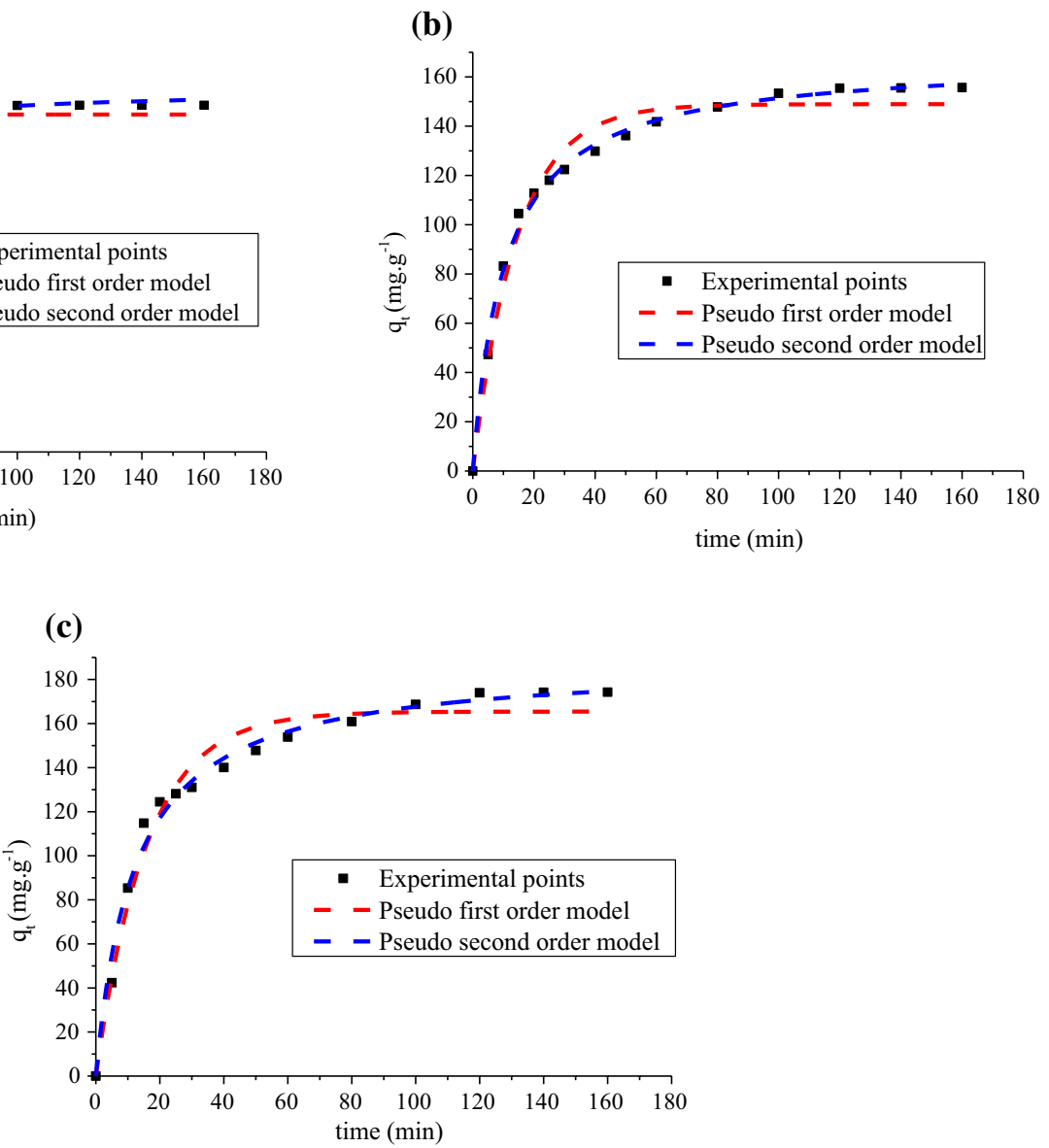

Fig. 7 Pseudo-first-order and pseudo-second-order models of AB25 adsorption onto WDS-AC at different concentrations a 90 mg $\mathrm{L}^{-1}$; $\mathbf{b}$ $130 \mathrm{mg} \mathrm{L}^{-1} ; \mathbf{c} 150 \mathrm{mg} \mathrm{L}^{-1}$ ) 
Table 5 Pseudo-first-order and pseudo-second-order models constants, correlation coefficients, and Chi-square statistical test for BA25 dye adsorption onto WDS-AC

\begin{tabular}{|c|c|c|c|c|c|c|c|c|}
\hline \multirow{3}{*}{$\begin{array}{l}\text { Initial con- } \\
\text { centration }\end{array}$} & \multicolumn{8}{|l|}{ Model } \\
\hline & \multicolumn{4}{|c|}{ Pseudo-first-order model } & \multicolumn{4}{|c|}{ Pseudo-second-order model } \\
\hline & $q_{e \mathrm{cal}}$ & $k_{l}$ & $R^{2}$ & $\chi^{2}$ & $q_{\text {ecal }}$ & $k_{2}$ & $R^{2}$ & $\chi^{2}$ \\
\hline 90 & 109.036 & 0.1203 & 0.9722 & 4.919 & 117.239 & $1.736 \times 10^{-3}$ & 0.9964 & 0.5135 \\
\hline 130 & 148.939 & 0.0702 & 0.9775 & 4.862 & 167.227 & $0.573 \times 10^{-3}$ & 0.9955 & 1.499 \\
\hline 150 & 165.439 & 0.0637 & 0.9714 & 7.191 & 187.919 & $0.440 \times 10^{-3}$ & 0.9882 & 4.892 \\
\hline
\end{tabular}

where $q_{t}\left(\mathrm{mg} \mathrm{g}^{-1}\right)$ is the amount of adsorbed AB25 at time $\mathrm{t}$, $k_{\text {dif }}\left(\mathrm{mg} \mathrm{g}^{-1} \mathrm{~min}^{-1 / 5}\right)$ the rate of intraparticle diffusion model and $\mathrm{C}$ the intercept, determined from the linear plots of $q_{t}$ versus $t^{0.5}$ (Fig. 8).

The intraparticle diffusion is the sole controlling step, if the plot of $q_{\mathrm{t}}$ versus $t^{1 / 2}$ satisfies the linear relationship and the $C$ value is fitted to zero (Islama et al. 2015). If not, the external diffusion and the boundary layer diffusion along with intraparticle diffusion are also involved in the adsorption process (Cheung et al. 2007; Zhou et al. 2019)

The evolution of $q_{t}$ versus $t^{0.5}$ (Fig. 8) is nonlinear, over the adsorption time; nevertheless, the process can be divided into three linear portions which do not pass by the origin whenever the AB25 concentration. This observation indicates that the intraparticle diffusion is not the ratecontrolling step and other mechanisms are involved of the

(a)

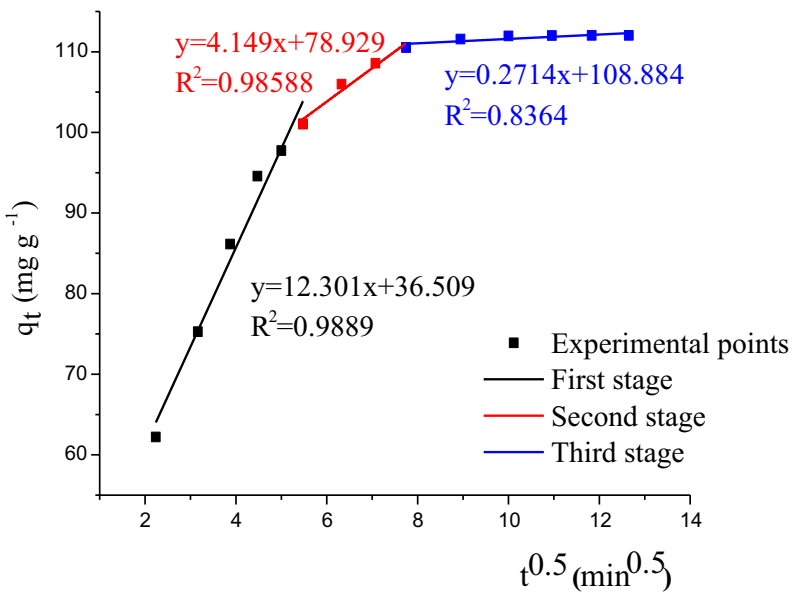

(b)

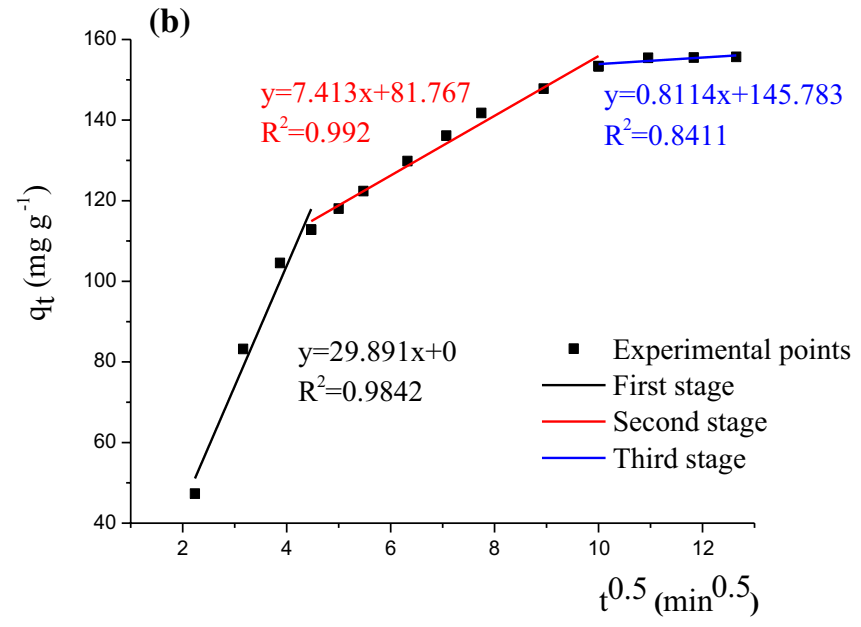

(c)

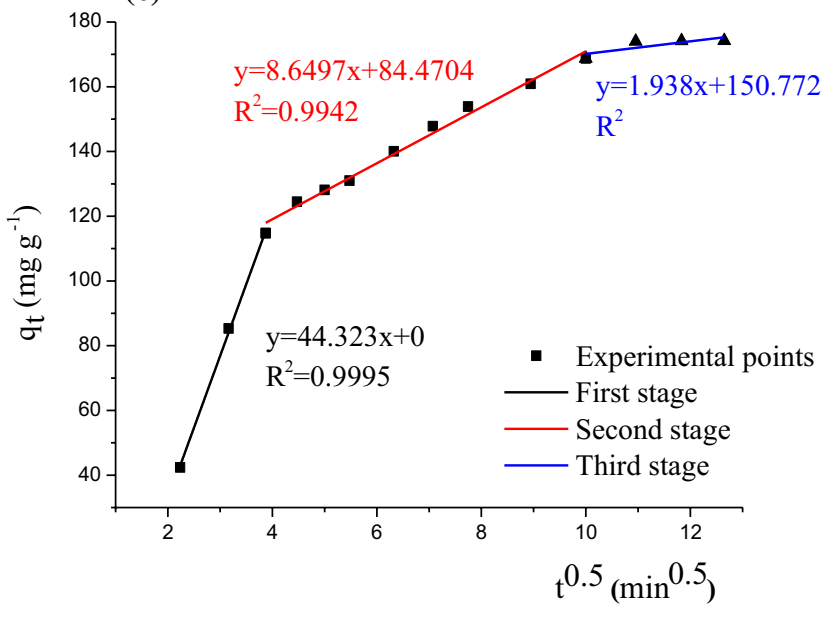

Fig. 8 Evolution of $q_{e}$ versus $t^{0.5}$ at different concentrations a $90 \mathrm{mg} \mathrm{L}^{-1}$; b $130 \mathrm{mg} \mathrm{L}^{-1}$; c $150 \mathrm{mg} \mathrm{L}^{-1}$ ) 
adsorption of AB25 onto WDS-AC (Deniz and Karaman 2011). The first linear form corresponds to the rapid external surface adsorption, i.e., the $\mathrm{AB} 25$ molecules are transferred to the easily accessible actives sites of the adsorbent which takes place at the film diffusion. The second line denotes intraparticle diffusion where the gradual adsorption stage is controlled. The third straight line indicates the last equilibrium step when the diffusion rate decreases and becomes stable by the diminution of the concentrations gradient between the adsorbate and adsorbent surface.

In the same way, the $C$ value presents a concept of the boundary layer thickness (De Luna et al. 2013). It can be noticed that for the three initial AB25 concentrations, the $k_{\text {dif }}$ values decrease with raising the $\mathrm{C}$ value. Such behavior is due to the increased boundary layer (Öztürk and Malkoc 2014), while the decrease in $k_{\text {dif }}$ is attributed to the driving force with the initial concentration $C_{0}$ and adsorption into both mesopores and micropores (Beltrame et al. 2018).

\section{Isotherm study}

In this work, the two-parameter models, namely the Langmuir, Freundlich, and Dubinin-Radushkevich (Table 6), were chosen to give an idea about the relationship between the distribution of the dye molecules in the liquid phase and in the solid surface at equilibrium (Jothirani et al. 2016; Suganya et al. 2017). The AB25 concentration ranges from 50 to $150 \mathrm{mg} \mathrm{L}^{-1}$, while other parameters were preserved at optimum conditions. The fitted data for different isotherm models are illustrated in Fig. 9 by nonlinear regression form using the ORIGIN 8.6 software, and their constants parameters along with $R^{2}$ and $\chi^{2}$ values are summarized, respectively, in Table 6.
On the basis of $R^{2}$ and $\chi^{2}$ values (Table 6), the isotherm data were suitably fitted by Langmuir model with the highest $R^{2}$ and lowest $\chi^{2}$ values. This result suggests that the AB25 adsorption occurs specific homogeneous sites and as a monolayer adsorption of AB25 onto WDS-AC (Asfaram et al. 2015; Ghaedi and Kokhdan 2015). Additionally, the mean free energy of transfer $(E)$ was determined to verify the nature of the adsorption process using the Dubinin-Radushkevich model. It is concluded from the $E$ value $\left(E=3.269 \mathrm{~kJ} \mathrm{~mol}^{-1}\right)$ that the adsorption proceeds through physical sorption (1-8 $\mathrm{kJ} \mathrm{mol}^{-1}$ ) (Khan et al. 2016).

In order to situate our novel adsorbent among those used to treat acid dyes from synthetic water, a comparison based on the maximum monolayer adsorption capacities was performed. The results (Table 7) showed that the WDS-AC possesses an excellent adsorption capacity when compared to

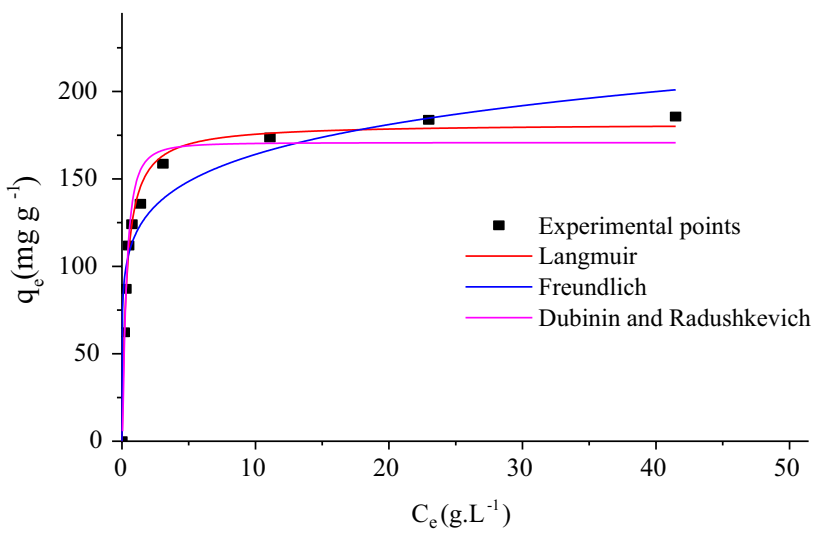

Fig. 9 Adsorption isotherm models fitted to experimental adsorption of $\mathrm{AB} 25$

Table 6 Summary of constants parameters for isotherm models and correlation coefficients estimated for the adsorption of AB25 onto WDS-AC

\begin{tabular}{|c|c|c|c|c|}
\hline Isotherm model & Equation & Parameters & Values & References \\
\hline \multirow[t]{4}{*}{ Langmuir } & \multirow{4}{*}{$q_{e}=\frac{q \max K_{L} C_{e}}{1+K_{L} C_{e}}$} & $q_{\max }\left(\mathrm{mg} \mathrm{g}^{-1}\right)$ & 181.59 & \multirow[t]{4}{*}{ Kumar et al. (2010a, b) } \\
\hline & & $k_{L}\left(\mathrm{~L} \mathrm{mg}^{-1}\right)$ & 2.905 & \\
\hline & & $R^{2}$ & 0.993 & \\
\hline & & $\chi^{2}$ & 1.397 & \\
\hline \multirow[t]{4}{*}{ Freundlich } & \multirow{4}{*}{$q_{e}=K_{F} C_{e}^{1 / n_{F}}$} & $K_{F}\left[\left(\mathrm{mg} \mathrm{g}^{1}\right)\left(\mathrm{L} \mathrm{mg}^{1}\right)^{1 / n}\right]$ & 118.08 & \multirow[t]{4}{*}{ Kumar et al. (2010a, b) } \\
\hline & & $1 / n_{F}$ & 0.143 & \\
\hline & & $R^{2}$ & 0.929 & \\
\hline & & $\chi^{2}$ & 17.912 & \\
\hline \multirow[t]{5}{*}{ Dubinin-Radushkevich } & \multicolumn{2}{|c|}{$q_{e=q \max _{D=R}} \times e^{\left[-\beta \times\left(R T \ln \left(1+\frac{q_{m}}{C_{e}}\right){ }^{2}\right)^{2}\right]_{-R}\left(\mathrm{mg} \mathrm{g}^{-1}\right)}$} & 170.76 & \multirow[t]{5}{*}{ Rangabhshiyam et al. (2014) } \\
\hline & \multirow{4}{*}{$E=\frac{1}{\sqrt{2 \beta}}$} & $\beta\left(\mathrm{mol}^{2} \mathrm{~kJ}^{-2}\right)$ & $4.68 * 10^{-8}$ & \\
\hline & & $E\left(\mathrm{~kJ} \mathrm{~mol}^{-1}\right)$ & 3.269 & \\
\hline & & $R^{2}$ & 0.962 & \\
\hline & & $\chi^{2}$ & 8.179 & \\
\hline
\end{tabular}


Table 7 Comparison of maximum monolayer adsorption capacities of acid dyes onto various adsorbents reported in the literature

\begin{tabular}{|c|c|c|c|c|}
\hline Adsorbents & Acid dyes & Experiment conditions & $\begin{array}{l}q_{\max } \\
\left(\mathrm{mg} \mathrm{g}^{-1}\right)\end{array}$ & References \\
\hline WDS-AC & Acid Blue 25 & $C_{\text {ads }}=0.4 \mathrm{~g} \mathrm{~L}^{-1} ; T=45^{\circ} \mathrm{C}$ & 181.59 & This study \\
\hline Modified Phragmites australis activated carbon & Acid Red 18 & $C_{\text {ads }}=0.4 \mathrm{~g} \mathrm{~L}^{-1} ; T=25^{\circ} \mathrm{C}$ & 115.93 & Wang et al. 2018 \\
\hline Rambutan peel activated carbon & Acid yellow 17 & $C_{\mathrm{ads}}=1 \mathrm{~g} \mathrm{~L}^{-1} ; T=30^{\circ} \mathrm{C}$ & 215.05 & Njoku et al. 2014 \\
\hline Waste tea activated carbon & Acid Blue 25 & $C_{\text {ads }}=1 \mathrm{~g} \mathrm{~L}^{-1} ; T=50^{\circ} \mathrm{C}$ & 180.23 & Auta and Hameed 2011 \\
\hline Spent bleaching sorbent activated carbon-clay & Acid Blue 29 & $C_{\text {ads }}=1 \mathrm{~g} / \mathrm{L} ; T=30^{\circ} \mathrm{C}$ & 104.83 & Marrakchi et al. 2017 \\
\hline Pericarp of pecan activated carbon & Acid Blue 25 & $C_{\text {ads }}=8 \mathrm{~g} \mathrm{~L}^{-1} ; T=30^{\circ} \mathrm{C}$ & 79 & Hernández-Montoya et al. 2011 \\
\hline Peanut shells activated carbon & Acid Yellow 36 & $C_{\text {ads }}=4 \mathrm{~g} \mathrm{~L}^{-1} ; T=35^{\circ} \mathrm{C}$ & 66.7 & Garg et al. 2019 \\
\hline
\end{tabular}

other adsorbents and could be recommended for the removal of dyes from the textile effluents.

\section{Conclusion}

In the present study, wild date stones were used as novel material for an activated carbon preparation to be applied for the removal of Acid Blue 25 dye from aqueous solution. The carbonization temperature of the raw material was selected at $850{ }^{\circ} \mathrm{C}$ using thermo-gravimetric analysis. Several structural characterization analyses such as BET, SEM and FTIR confirmed the successful activation and carbonization of precursor. The BET surface area of activated carbon was found to be $611 \mathrm{~m}^{2} \mathrm{~g}^{-1}$. The central composite design (CCD) was used to optimize significant adsorption variables including the initial dye concentration, adsorbent dose, temperature, and time, and the optimum conditions for $99.61 \%$ removal of AB25 dye from synthetic water were achieved to be initial AB25 concentration of $100 \mathrm{mg} \mathrm{L}^{-1}$, adsorbent dose $\left(0.8 \mathrm{~g} \mathrm{~L}^{-1}\right)$, temperature $\left(45^{\circ} \mathrm{C}\right)$, and adsorption time (120 min). Analysis of variance (ANOVA) was suggested that the experimental data were fitted to the quadratic model. The analysis of kinetics data revealed the pseudo-secondorder model was the best fitted model, while the intraparticle diffusion model is not the only controlling step; other mechanisms might be involved in the adsorption process. The Langmuir isotherm provided the best fit with the high correlation coefficient $\left(R^{2}\right)$ of 0.993 and the maximum monolayer adsorption capacity of $181.59 \mathrm{mg} \mathrm{g}^{-1}$. Finally, the results showed that the wild date stones as a low-cost material may be a suitable alternative for the elimination of AB25 from colored synthetic water.

Acknowledgements The financial support of the work was provided by the Faculty of Chemistry.

\section{Compliance with ethical standards}

Conflict of interest The authors attest that there are no conflict of interest and financial, personal, or other relationships with other people, laboratories, or organizations worldwide.

Open Access This article is distributed under the terms of the Creative Commons Attribution 4.0 International License (http://creativecommons.org/licenses/by/4.0/), which permits unrestricted use, distribution, and reproduction in any medium, provided you give appropriate credit to the original author(s) and the source, provide a link to the Creative Commons license, and indicate if changes were made.

\section{References}

Aljeboree A, Alshirifi AN, Alkaim AF (2017) Kinetics and equilibrium study for the adsorption of textile dyes on coconut shell activated carbon. Arab J Chem 10:3381-3393

Amin NK (2009) Removal of direct blue-106 dye from aqueous solution using new activated carbons developed from pomegranate peel: adsorption equilibrium and kinetics. J Hazard Mater 52:62-165

Anithaa T, Kumar PS, Kumar KS (2016) Synthesis of nano-sized chitosan blended polyvinyl alcohol for the removal of Eosin Yellow dye from aqueous solution. J Water Process Eng 13:127-136

Arulkumar M, Sathishkumar P, Palvannan T (2011) Optimization of Orange $\mathrm{G}$ dye adsorption by activated carbon of the spesiapopulnea pods using response surface methodology. J Hazard Mater $186: 827-834$

Asfaram A, Ghaedi M, Hajati S, Rezaeinejad M, Goudarzi A, Purkait MK (2015) Rapid removal of Auramine-O and Methylene blue by $\mathrm{ZnS}$ : $\mathrm{Cu}$ nanoparticles loaded on activated carbon: a response surface methodology approach. J Taiwan Inst Chem Eng 53:80-91

Asfaram A, Ghaedi M, Yousefi F, Dastkhoon M (2016) Experimental design and modeling of ultrasound assisted simultaneous adsorption of cationic dyes onto $\mathrm{ZnS}$ : Mn-NPs-AC from binary mixture. Utrason Sonochem 33:77-89

Auta M, Hameed BH (2011) Preparation of waste tea activated carbon using potassium acetate as an activating agent for adsorption of Acid Blue 25 dye. Chem Eng J 171:502-509

Azargohar R, Dalai AK (2005) Production of activated carbon from Luscar char: experimental and modeling studies. Microporous Mesoporous Mater 85:219-225

Bardajee GR, Azimi S, Sharifi MBAS (2017) Application of central composite design for methyl red dispersive solid phase extraction based on silver nanocomposite hydrogel: microwave assisted synthesis. Microchem J 133:358-369

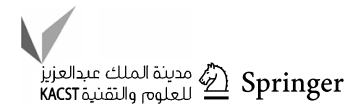


Beltrame KK, Cazetta AL, De Souza PSC, Spessato L, Silva TL, Almeida VC (2018) Adsorption of caffeine on mesoporous activated carbon fibers prepared from pineapple plant leaves. Ecotoxicol Environ Saf 147:64-71

Bouhamidi Y, Kaouah F, Nouri L, Boumaza S, Trari M, Bendjama $\mathrm{Z}$ (2018) Kinetic, thermodynamic, and isosteric heat of dibutyl and diethyl phthalate removal onto activated carbon from Albizzia julibrissin pods. Part Sci Technol 36:235-243

Boumaza S, Kaouah F, Berrama T, Trari M, Bendjama Z (2012) Optimization of preparation conditions for activated carbon from waste materials of agricultural origin for the removal of basic red 46. Chemom Intell Lab Syst 118:311-316

Chatterjee S, Kumar A, Basu S, Duttaa S (2012) Application of response surface methodology for Methylene Blue dye removal from aqueous solution using low cost adsorbent. Chem Eng J 181:289-299

Cheng Z, Zhang L, Guo X, Jiang X, Liu R (2015) Removal of Lissaminerhodamine $\mathrm{B}$ and acid orange 10 from aqueous solution using activated carbon/surfactant: process optimization, kinetics and equilibrium. J Taiwan Inst Chem Eng 47:149-159

Cheung WH, Szeto YS, McKay G (2007) Intraparticle diffusion processes during acid dye adsorption onto chitosan. Bioresour Technol 98:2897-2904

Cronje KJ, Chetty K, Carsky M, Sahu JN, Meikap BC (2011) Optimazation of chromium (VI) sorption potential using developed activated carbon from sugarcane bagasse with chemical activation by zinc chloride. Desalin 275:276-284

Dashamiri S, Ghaedi M, Asfarama A, Zare F, Wang S (2017) Optimization of ultrasound assisted competitive adsorption of dyes onto $\mathrm{Cu}(\mathrm{OH})_{2}$-nanoparticle loaded activated carbon: central composite design. Ultrason Sonochem 34:343-353

Dastkhoon M, Ghaedi M, Asfaram A, Goudarzi A, Langroodi SM, Tyagi I, Agrarwal S, Gupta VK (2015) Ultrasound assisted adsorption of malachite green dye onto $\mathrm{ZnS}: \mathrm{Cu}-\mathrm{NP}-\mathrm{AC}$ : Equilibrium isotherms and kinetic studies-response surface optimization. Sep Purif Technol 156:780-788

De Luna MDG, Flores ED, Genuino DAD, Futalan CM, Wan MW (2013) Adsorption of Eriochrome Black T (EBT) dye using activated carbon prepared from waste rice hulls: optimization, isotherm and kinetic studies. J Taiwan Inst Chem Eng 44:646-653

Deniz F, Karaman S (2011) Removal of an azo-metal complex textile dye from colored aqueous solutions using an agro-residue. Microchem J 99:296-302

Deze EG, Papageorgiou SG, Favvas EP, Katsaros FK (2012) Porous alginate aerogel beads for effective and rapid heavy metal sorption from aqueous solutions: effect of porosity in $\mathrm{Cu}^{2+}$ and $\mathrm{Cd}^{2+}$ ion sorption. Chem Eng J 209:537-546

Fakhri A (2015) Investigation of mercury (II) adsorption from aqueous solution onto copper oxide nanoparticles: optimization using response surface methodology. Process Saf Environ Prot 93:1-8

Fernandez ME, Nunell GV, Bonelli PR, Cukierman AL (2014) Activated carbon developed from orange peels: batch and dynamic competitive adsorption of basic dyes. Ind Crops Prod 62:437-445

Garba ZN, Bello I, Galadima A, Lawal AY (2016) Optimization of adsorption conditions using central composite design for the removal of copper (II) and lead (II) by defatted papaya seed. Karbala Int J Mod Sci 2:20-28

Garg D, Kumar S, Sharma K, Majumder CB (2019) Application of waste peanut shells to form activated carbon and its utilization for the removal of Acid Yellow 36 from wastewater. Groundwater Sustain Dev 8:512-519

Georgin J, Dotto GL, Mazutti MA, Foletto EL (2016) Preparation of activated carbon from peanut shell by conventional pyrolysis and microwave irradiation-pyrolysis to remove organic dyes from aqueous solutions. J Environ Chem Eng 4:266-275
Ghaedi M, Kokhdan SN (2015) Removal of methylene blue from aqueous solution by wood millet carbon optimization using response surface methodology. Spectrochim Acta A: Mol Biomol Spectrosc 136:141-148

Ghaedi M, Azad FN, Dashtian K, Hajati S, Goudarzi A, Soylak M (2016) Central composite design and genetic algorithm applied for the optimization of ultrasonic-assisted removal of malachite green by $\mathrm{ZnO}$ Nanorod-loaded activated carbon. Spectrochim Acta A: Mol Biomol Spectrosc 167:157-164

Giannakoudakis DA, Kyzas GZ, Avranas A, Lazaridis NK (2015) Multi-parametric adsorption effects of the reactive dye removal with commercial activated carbons. J Mol Liq 213:381-389

Hernández-Montoya V, Mendoza-Castillo DI, Bonilla-Petriciolet A, Montes-Moránb MA, Pérez-Cruz MA (2011) Role of the pericarp of Carya illinoinensisas biosorbent and as precursor of activated carbon for the removal of lead and acid blue 25 in aqueous solutions. J Anal Appl Pyrolysis 92:143-151

Hou D, Goei R, Wang P, Lim TT (2012) Preparation of carbon-sensitized and $\mathrm{Fe}-$ Ercodoped $\mathrm{TiO}_{2}$ with response surface methodology for bisphenol A photocatalytic degradation under visible-light irradiation. Appl Catal B: Environ 126:121-133

Islama MA, Benhouria A, Asif M, Hameed BH (2015) Methylene blue adsorption on factory-rejected tea activated carbon prepared by conjunction of hydrothermal carbonization and sodium hydroxide activation processes. J Taiwan Inst Chem E 52:57-64

Jamshidi M, Ghaedi M, Dashtiana K, Ghaedi AM, Hajati S, Goudarzi A, Alipanahpoura E (2016) Highly efficient simultaneous ultrasonic assisted adsorption of brilliant green and eosin $\mathrm{B}$ onto $\mathrm{ZnS}$ nanoparticles loaded activated carbon: artificial neural network modeling and central composite design optimization. Spectrochim Acta A: Mol Biomol Spectrosc 153:257-267

Jothirani R, Kumar PS, Saravanan A, Narayan AS, Dutta A (2016) Ultrasonic modified corn pith for the sequestration of dye from aqueous solution. J Ind Eng Chem 39:162-175

Kaçan E, Kütahyah C (2012) Adsorption of strontium from aqueous solution using activated carbon produced from textile sewage sludges. J Anal Appl Pyrolysis 97:149-157

Kaouah F, Boumaza S, Berrama T, Trari M (2013) Preparation and characterization of activated carbon from wild olive cores (oleaster) by $\mathrm{H}_{3} \mathrm{PO}_{4}$ for the removal of Basic Red 46. J Clean Prod 54:296-306

Khan TA, Khan EA (2016) Adsorptive of basic dyes from aqueous solution by novel brown linseed deoiled cake activated carbon: equilibrium isotherms and dynamics. J Environ Chem Eng 4:3084-3095

Khan TA, Sharma S, Ali I (2011) Adsorption of Rhodamine B dye from aqueous solution onto acid activated mango (Magnifera indica) leaf powder: equilibrium, kinetic and thermodynamic studies. J Toxicol Environ Health Sci 3:286-297

Köseoğlu E, Başar CA (2015) Preparation, structural evaluation and adsorptive properties of activated carbon from agricultural waste biomass. Adv Powder Technol 26:811-818

Kumar PS, Subramaniam R (2013) Process optimization studies of Congo red dye adsorption onto cashew nut shell using response surface methodology. Int J Ind Chem 4(1): 17

Kumar PS, Ramalingam S, Senthamarai C, Niranjanaa M, Vijayalakshmi P, Sivanesan S (2010a) Adsorption of dye from aqueous solution by cashew nut shell: studies on equilibrium isotherm, kinetics and thermodynamics of interactions. Desalin 261:52-60

Kumar PS, Ramalingam S, Senthamarai C, Niranjanaa M, Vijayalakshmi P, Sivanesan S (2010b) Adsorption of dye from aqueous solution by cashew nut shell: studies on equilibrium isotherm, kinetics and thermodynamics of interactions. Desalin 261:52-60

Kumar PS, Abhinaya RV, Lashmi KG, Arthi V, Pavithra R, Sathyaselvabala V, Sivanesan S (2011) Adsorption of methylene blue dye from aqueous solution by agricultural waste: equilibrium, 
thermodynamics, kinetics, mechanism and process design. Colloid J 73:651-661

Kumar PS, Fernando PSA, Ahmed RT, Srinath R, Priyadharshini M, Vignesh AM, Thanjiappan A (2014a) Effect of temperature on the adsorption of methylene blue dye onto sulfuric acid-treated orange peel. Chem Eng Commun 201:1526-1547

Kumar PS, Sivaranjanee R, Vinothini U, Raghavi M, Rajasekar K, Ramakrishnan K (2014b) Adsorption of dye onto raw and surface modified tamarind seeds: isotherms, process design, kinetics and mechanism. Desalin Water Treat 52:2620-2633

Kumar PS, Pavithra J, Suriya S, Ramesh M, Kumar KA (2015) Sargassum wightii, a marine algae is the source for the production of algal oil, bio-oil and application in the dye wastewater treatment. Desalin Water Treat 55:1342-1358

Kumar PS, Varjani SJ, Suganya S (2018) Treatment of dye wastewater using an ultrasonic aided nanoparticle stacked activated carbon: kinetic and isotherm modeling. Bioresour Technol 250:716-722

Marrakchi F, Bouaziz M, Hameed BH (2017) Activated carbon-clay composite as an effective adsorbent from the spent bleaching sorbent of olive pomace oil: process optimization and adsorption of acid blue 29 and methylene blue. Chem Eng Res Des 128:221-230

Mazaheri H, Ghaedi M, Asfaram A, Hajati S (2016) Performance of $\mathrm{CuS}$ nanoparticle loaded on activated carbon in the adsorption of methylene blue and bromophenol blue dyes in binary aqueous solutions: using ultrasound power and optimization by central composite design. J Mol Liq 219:667-676

Njoku VO, Foo KY, Asif M, Hameed BH (2014) Preparation of activated carbons from rambutan (Nephelium lappaceum) peel by microwave-induced $\mathrm{KOH}$ activation for acid yellow 17 dye adsorption. Chem Eng J 250:198-204

Öztürk A, Malkoc E (2014) Adsorptive potential of cationic Basic Yellow 2 (BY2) dye onto natural untreated clay (NUC) from aqueous phase: mass transfer analysis kinetic and equilibrium profile. Appl Surf Sci 299:105-115

Prola LPT, Machado FM, Bergmann CP, Souza FE, Gally CR, Lima EC, Adebayo MA, Dias SLP, Alvete T (2013) Adsorption of Direct Blue 53 dye from aqueous solutions by multi-walled carbon nanotubes and activated carbon. J Environ Manag 130:166-175

Puchana-Rosero MJ, Adebayo MA, Lima EC, Machado FM, Thue PS, Vaghetti JCP, Umpierres CS, Gutterres M (2016) Microwaveassisted activated carbon obtained from the sludge of tannerytreatment effluent plant for removal of leather dyes. Colloids Surf A: Physico chem Eng Asp 504:105-115

Rangabhshiyam S, Anu N, Nandagopal MSG, Selvaraju N (2014) Relevance of isotherm models in biosrption of pollutants by agricultural byproducts. J Environ Chem Eng 2:398-414

Roosta M, Ghadi M, Mohammadi M (2014) Removal of Alizarin Red $\mathrm{S}$ by gold nanoparticles loaded on activated carbon combined with ultrasound device: optimization by experimental design methodology. Powder Technol 267:134-144

Sayğ $\breve{l l}_{1}$ H, Güzel F (2016) Effective removal of tetracycline from aqueous solution using activated carbon prepared from tomato (Lycopersiconesculentum Mill.) industrial processing waste. Ecotoxicol Environ Saf 131:22-29

Senthamarai C, Kumar PS, Priyadharshini M, Vijayalakshmi P, Vinoth Kumar V, Baskaralingam P, Thiruvengadaravi KV, Sivanesan S (2013) Adsorption behavior of methylene blue dye onto surface modified Strychnos potatorum seeds. Environ Prog Sustain Energy 32:624-632

Setiabudi HD, Jusoh R, Suhaimi SFRM, Masrur SF (2016) Adsorption of methylene blue onto oil palm (Elaeisguineensis) leaves: process optimization, isotherm, kinetics and thermodynamic studies. J Taiwan Inst Chem Eng 63:363-370

Sivarajasekar N, Baskar R (2014) Adsorption of basic red 9 on activated waste Gossypiumhirsutum seeds: process modeling, analysis and optimization using statistical design. J Ind Eng Chem 20:2699-2709

Suganya S, Kumar PS, Saravanan A, Rajan PS, Ravikumar C (2017) Computation of adsorption parameters for the removal of dye from wastewater by microwave assisted sawdust: theoretical and experimental analysis. Environ Toxicol Pharmacol 50:45-57

Unuabonah EI, Adie GU, Onah LO, Adeyemi OG (2009) Multistage optimization of the adsorption of methylene blue dye onto defatted Carica papaya seeds. Chem Eng J 155:567-579

Vecino X, Devesa-Rey R, Moldes AB, Cruz JM (2012) Optimization of batch operating conditions for the decolourization of vinasses using surface response methodology. Microchem J 102:83-90

Wang L, Chen Z, Wen H, Cai Z, He C, Wang Z, Yan W (2018) Microwave assisted modification of activated carbons by organic acid ammoniums activation for enhanced adsorption of acid red 18 . Powder Technol 323:230-237

Weber WJ, Morris JC (1963) Kinetics of adsorption on carbon from solutions. J Sanit Eng Div 89:31-60

Zhou L, Zhou H, Hu Y, Yan S, Yang J (2019) Adsorption removal of cationic dyes from aqueous solutions using ceramic adsorbents prepared from industrial waste coal gangue. J Environ Manag $234: 245-252$

Publisher's Note Springer Nature remains neutral with regard to jurisdictional claims in published maps and institutional affiliations. 